\title{
DEVELOPMENT OF GLOBULAR EMBRYOS FROM THE HYBRIDIZATION BETWEEN 'PÊRA RIO' SWEET ORANGE AND 'PONCÃ' MANDARIN'
}

\author{
EDVAN ALVES CHAGAS 2 , MOACIR PASQUAL ${ }^{3}$, JOSÉ DARLAN RAMOS ${ }^{3}$, POLLYANA CARDOSO $^{4}$, \\ JAIRO OSVALDO CAZETTA², MILENE ALVES DE FIGUEIREDO ${ }^{3}$
}

\begin{abstract}
This research was undertaken to study the influence of different concentrations of the MT medium, sucrose, vitamins, activated charcoal and gibberellic acid ( $\mathrm{GA}_{3}$ ) on the culture of immature embryos from the crossing between 'Pêra Rio' sweet orange and 'Poncã' mandarin. The embryos were excised under aseptic conditions and inoculated in $15 \mathrm{~mL}$ of the MT medium according to the following experiments: 1) MT concentrations $(0 \%, 50 \%, 100 \%, 150 \%$ and $200 \%)$ supplemented with $0,30,60$ and 90 g. $\mathrm{L}^{-1}$ of sucrose; 2$)$ vitamins concentrations of the MT ( $0 \%$, $50 \%, 100 \%, 150 \%$ and $200 \%)$ supplemented with $0,30,60$ and 90 g.L. $\mathrm{L}^{-1}$ of sucrose; 3$)$ activated charcoal concentrations $\left(0,0.5,1,1.5\right.$ and 2 g.L $\left.\mathrm{L}^{-1}\right)$ supplemented with $\mathrm{GA}_{3}\left(0,0.01,0.1 ; 1\right.$ and $\left.10 \mathrm{mg} \cdot \mathrm{L}^{-1}\right)$. After the inoculation, the embryos were kept in a growth room for 90 days at $27 \pm 1^{\circ} \mathrm{C}$, in a $16-$ hour photoperiod with $32 \mu \mathrm{mol} . \mathrm{m}^{-2} . \mathrm{s}^{-1}$ of irradiance. The best development of embryos at the globular stage was achieved using $50 \%$ and $100 \%$ of the MT medium plus 60 g.L.-1 and 90 g.L $\mathrm{L}^{-1}$ of sucrose, respectively, supplemented with $0.01 \mathrm{mg} . \mathrm{L}^{-1}$ of GA. The addition of activated charcoal or vitamins in the MT medium has shown to be unnecessary to the development of globular embryos.
\end{abstract}

Index terms: embryo culture, tissue culture, biotechnology, citrus breeding

\section{DESENVOLVIMENTO DE EMBRIÕES GLOBULARES DE CITROS PROVENIENTES DE HIBRIDAÇÃO ENTRE LARANJEIRA 'PÊRA RIO' $x$ TANGERINEIRA 'PONC $\tilde{A}$ '}

RESUMO - Objetivou-se estudar a influência de diversas concentrações do meio MT, sacarose, vitaminas, carvão ativado e ácido giberélico no cultivo de embriões imaturos oriundos do cruzamento entre laranjeira 'Pêra Rio' x tangerineira 'Poncã'. Os embriões foram excisados sob condições assépticas e inoculados em $15 \mathrm{~mL}$ do meio de cultura MT, de acordo com cada experimento a seguir: 1$)$ concentrações do meio de cultura MT ( $0 \%$, $50 \%, 100 \%, 150 \%$ e $200 \%$ ) combinados com $0,30,60$ e 90 g.L.-1 de sacarose; 2$)$ concentrações de vitaminas do meio MT $(0 \%, 50 \%, 100 \%, 150 \%$ e $200 \%$ ) combinados com $0,30,60$ e 90 g.L - $^{-1}$ de sacarose e; 3$)$ concentrações de carvão ativado $\left(0 ; 0.5 ; 1 ; 1.5\right.$ e 2 g.L $\left.L^{-1}\right)$ combinados com GA $(0 ; 0.01$; $0.1 ; 1$ e $\left.10 \mathrm{mg} \cdot \mathrm{L}^{-1}\right)$. Após a inoculação, os embriões foram mantidos por 90 dias em sala de crescimento à temperatura de $27 \pm 1^{\circ} \mathrm{C}$, fotoperíodo de 16 horas e irradiância de $32 \mu \mathrm{mol} . \mathrm{m}^{-2} . \mathrm{s}^{-1}$. A utilização de $50 \%$ e $100 \%$ do meio MT associado a $60 \mathrm{e} 90 \mathrm{~g} . \mathrm{L}^{-1}$ de sacarose, respectivamente, acrescido de $0.01 \mathrm{mg} . \mathrm{L}^{-1}$ de $\mathrm{GA}_{3}$, proporcionou melhor desenvolvimento de embriões globulares. Não houve necessidade da adição de carvão ativado e vitaminas no meio MT para o cultivo de embriões globulares.

Termos para indexação: cultura de embriões, cultura de tecidos, biotecnologia, melhoramento genético.

\section{INTRODUCTION}

The appearance of diseases like the citrus variegated clorosis (CVC), citrus canker, citrus decline, citrus sudden death, and recently the alternaria spotting of tangerines has taken the production of citrus to a very delicate situation. Therefore, great effort has been made to develop new resistant varieties. However, several pitfalls are commonly faced in developing these new citrus varieties, e.g. the gametic sterility, the long duration of the young stage, species incompatibilities (Soost \& Cameron, 1975 ) and especially the high rate of polyembriony, which is very common amongst species of this genus (Soost et al., 1980). The latter normally results in the abortion of the zygotic embryo, due to the competition with the nucellar embryos, which are often more vigorous. Within this context, the embryo culture is very important because it makes possible the use of immature hybrid embryos (Hu \& Ferreira, 1998) through an appropriate in vitro procedure (Sharma et al., 1996), and an adequate culture medium. Generally, the success of this technique depends on the stage the embryo is excised and the composition of the medium used for germination. However, the younger the embryo is, the harder is the in vitro culture, mainly because of its small size, high risk damage during excision and complex nutritional needs (Hu \& Ferreira, 1998). This way, defining a culture medium that renders the development of immature embryos is the most important aspect of in vitro culture (Pasqual et al., 2001).

White's medium (White, 1943) was extensively used as a basic medium to the culture of a variety of tissues from many species (Caldas et al., 1998). A number of adaptations have been made in this medium to each specific situation, and the increase of salt concentrations, reduction of sodium and increase of nitrogen both as ammonium or nitrate, resulted in the MS medium (Murashige \& Skoog, 1962). Later, Murashige \& Tucker (1969) formulated a culture medium suitable to in vitro propagation of citrus. Besides the adjustments in sucrose and vitamins concentrations, other changes like the addition of hydrolyzed casein and malt extract were made by these authors. Other alternatives are being searched, especially the ones closer to the composition of the endosperm or the embryonic sac which can make possible the development of embryos of whatever stage (Andreoli, 1986).

In the specific case of citrus, many researches have been made in an attempt to adjust the diverse factors of in vitro embryo culture, e.g. $\mathrm{pH}$, agar, MS concentrations, sucrose, gibberellic acid and activated charcoal (Ribeiro et al., 1997, 1998, 1999b, 2000). The best concentrations of macro and micronutrients, vitamins and complex mixtures of the MT medium are being studied (Morais, 1997), as well as the identification of the most appropriate developmental stage of the embryo (Ribeiro et al., 1999a).

The quantitative and qualitative carbohydrate content plays an important role in maintaining the correct osmolarity of the medium and in promoting leaf primordium growth (Pasqual \& Pinto, 1988). In general, embryos at initial development stages need high sucrose concentrations, between 12\% and 18\%(Caldas et al., 1998), while for Citrus, the optimal concentrations vary from $2 \%$ to $7 \%$, according to the explant (Navarro et al., 1985). In many media, vitamins and amino acids are added (George, 1993). The need for vitamins depends on the species and the kind of culture. It has been shown that one or even all the vitamins are unnecessary to some cultures and species (Pasqual et al., 2001).

The activated charcoal promotes embryo growth by sorbing inhibitors released in the medium by the explants and is successfully

${ }^{1}$ (Trabalho 067/2003). Recebido: 11/06/2003. Aceito para publicação: 15/08/2003. Part of the dissertation presented to Universidade Federal de Lavras (UFLA) as a requirement for the Master's degree.

${ }^{2}$ FCAV/UNESP - Departamento de Tecnologia, Rua Prof. Paulo Donato Castellane, s/n, 14884-900. Jaboticabal, SP. E-mail: cazetta@fcav.unesp.br, edyvanchagas@bol.com.br.

${ }^{3}$ Departamento de Agricultura, Universidade Federal de Lavras (UFLA). Cx. Postal, 37, 37200-000. Lavras, MG. E-mail: mpasqual@ufla.br.

${ }^{4}$ Undergraduate student at Universidade Federal de Lavras (UFLA), Lavras, MG. E-mail: pottycar@bol.com.br. 
used in many cultures in concentrations from $0.2 \%$ to $3 \%$ (Pasqual et al., 2001). Besides, it can benefit rooting since it reduces light intensity in the region roots are formed (Grattapaglia \& Machado, 1998).

Gibberellins have several physiological roles in plants, especially in cell elongation (Crocomo \& Cabral, 1988). Therefore, the use of gibberellins in tissue culture aims to promote natural ontogenic development of embryos lacking the root primordium or allow the development of an existing root zone.

Regarding the many constituents of culture media, our objective was to study the influence of several components of the MT medium (Murashige \& Tucker, 1969) in the culture of immature embryos from the controlled crossing between 'Pêra Rio' sweet orange (Citrus sinensis Osbeck.) and 'Poncã' mandarin (Citrus reticulata Blanco).

\section{MATERIALSAND METHODS}

The experiments were conducted in two stages: the first corresponded to controlled hybridizations between 'Pêra Rio' sweet orange and 'Poncã' mandarin, male and female parents, respectivelly, at the didactic orchard of Universidade Federal de Lavras (UFLA), Lavras, MG Brazil from September to October 2001. The second stage was the in vitro culture of embryos from fruits harvested between January and February 2002, at the Laboratório de Cultura de Tecidos Vegetais of Departamento de Agricultura, UFLA. Fruits were collected at 118 days after pollination, with 3 to $4 \mathrm{~cm}$ of diameter. Seeds were removed and treated with ethanol $70 \%$ for five minutes, then with sodium hypochlorite $2 \%$ for 20 minutes and finally washed three times in distilled water and autoclaved.

Seeds teguments were separated longitudinally by the region opposed to the micropyle with the help of a stereoscopic microscope, with the care of not damaging embryos.

Embryos at the globular stage were excised in aseptic conditions and inoculated individually in $15 \mathrm{~mL}$ of MT medium (Murashige \& Tucker, 1969), used as a basic medium composed of salts, vitamins, sucrose, malt extracts and hydrolyzed casein, and from which modifications were made

A

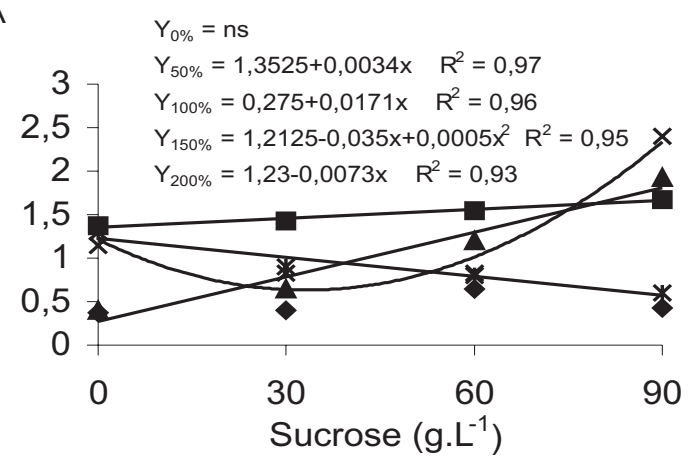

C

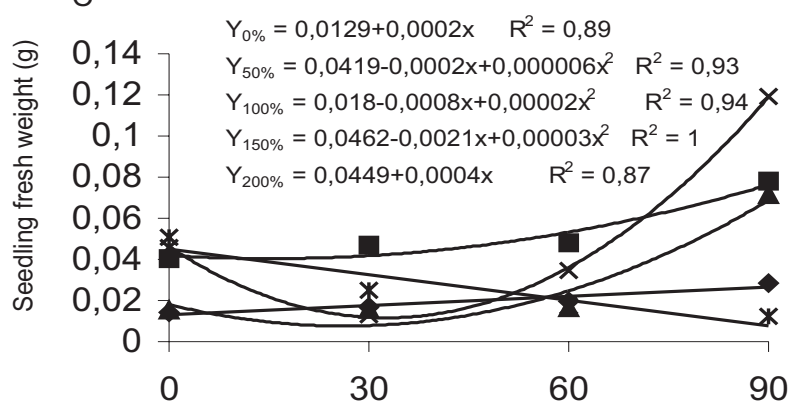

Sucrose $\left(g \cdot \mathrm{L}^{-1}\right)$ as follows to each of the three experiments:

Experiment 1 - MT medium $x$ sucrose: were studied concentrations of the medium MT $(0 \%, 50 \%, 100 \%, 150 \%$ and $200 \%)$ supplemented with $0,30,60$ e 90 g.L. $\mathrm{L}^{-1}$ of sucrose. The statistical design was completely randomized, in a $5 \times 4$ factorial arrangement with four replications, each one composed of three test tubes.

Experiment 2 - vitamins x sucrose: were studied vitamins concentrations $(0 \%, 50 \%, 100 \%, 150 \%$ and $200 \%$ of the original medium) supplemented with $0,30,60$ e 90 g.L $\mathrm{L}^{-1}$ of sucrose. The statistical design was completely randomized, in a $5 \times 4$ factorial arrangement with four replications, each one composed of three test tubes.

Experiment 3 - activated charcoal $x$ gibberellin $\left(\mathbf{G A}_{3}\right)$ : different concentrations of activated charcoal $\left(0 ; 0.5 ; 1 ; 1.5\right.$ and 2 g. $\left.\mathrm{L}^{-1}\right)$ supplemented with $\mathrm{GA}_{3}\left(0 ; 0.01 ; 0.1 ; 1 \mathrm{e} 10 \mathrm{mg} . \mathrm{L}^{-1}\right)$, plus $50 \mathrm{~g} . \mathrm{L}^{-1}$ of sucrose. The statistical design was completely randomized, in a $5 \times 5$ factorial arrangement with four replications, each one composed of three test tubes.

After excision and inoculation, embryos were incubated in a growth room at $27 \pm 1^{\circ} \mathrm{C}$, in a 16 -hour photoperiod with $32 \mu \mathrm{mol} \cdot \mathrm{m}^{-2} \cdot \mathrm{s}^{-1}$ of irradiance.

In all experiments seedlings were evaluated after 90 days based on the shoot and root length, fresh weight and number of leaves.

Data were submitted to ANOVA and the results compared through polynomial regression, according to each experiment, using the software SISVAR (Ferreira, 2000).

\section{RESULTSAND DISCUSSION}

\section{Experiment 1 - MT medium $x$ sucrose}

The best development of embryos were reached with the use of $50 \%, 100 \%$ and $150 \%$ of the MT medium supplemented with 90 g.L $\mathrm{L}^{-1}$ of sucrose (Figures 1A, 1B, 1C and 1D). The increment observed in the variables as the concentrations of the culture medium increased is in accordance with the results obtained by Sharp et al. (1971), who found
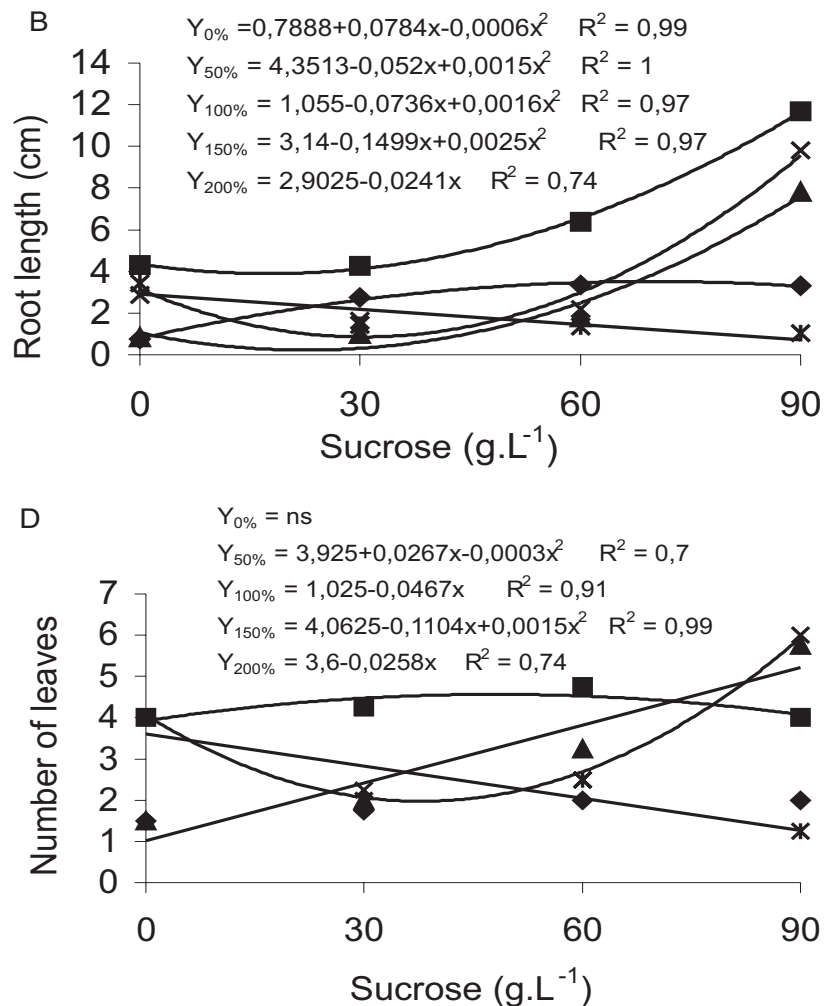

$0 \quad \square 0 \quad \Delta 100 \quad \mathrm{x} 150 \quad * 200$

FIGURE 1 -Shoot length (A), root length (B), fresh weight (C) and number of leaves (D) of the seedlings from immature embryos of the controlled crossing between 'Pêra Rio' sweet orange and 'Poncã' mandarin as grown in different concentrations of the medium MT and sucrose. UFLA, Lavras, MG 2002. 
that high concentrations of the medium stimulated the formation of embryos from tobacco anthers. Media with high salt concentrations, like MS (Murashige \& Skoog, 1962) and MT (Murashige \& Tucker, 1969), have been used in embryo culture because of their positive effect on growth and development of somatic embryos. Kunitake et al. (1991), using 'Satsuma' mandarin embryos at the heart-shaped stage, observed that $50 \%$ of the MT medium salt concentration supplemented with 1 mg. $\mathrm{L}^{-1}$ of GA $\mathrm{A}_{3}$ and $10 \mathrm{~g} . \mathrm{L}^{-1}$ of sucrose have not provided good conditions to in vitro culture of embryos, since only $5 \%$ of the embryos had normal development, with $50 \%$ to $60 \%$ of the regenerated plants showing abnormal growth. However, these results partly disagree with Ammirato \& Steward (1971), who observed better development of the proembryonic structures using a medium with low salt concentration, as White's medium (White, 1943), probably due to the low sucrose concentration.

The benefic effect of high sucrose concentrations proves the importance of this carbohydrate to embryo culture, and is in accordance with Caldas et al. (1998) because according to these authors embryos at initial stages need high concentrations of sucrose. Carimi et al. (1998) also observed that the germination and development of embryos of two Citrus aurantium genotypes were significantly lower at low (0 and 5 g. $\left.\mathrm{L}^{-1}\right)$ sucrose concentrations, while the opposite behavior was seen at high concentrations $\left(50\right.$ g.L $\left.\mathrm{L}^{-1}\right)$.

Besides contributing to optimal growth, supporting the highest growth rates in most species, high sucrose concentrations also have an important role in maintaining the adequate osmolarity of the medium (Hu \& Ferreira, 1998), especially avoiding mineral toxicity when its concentration is high in the culture medium.

The reduction of the MT concentration to $50 \%$ of the original was enough to the development of citrus immature embryos, which is also important on reducing costs. Ribeiro et al. (1998) studying the behavior of 'Pêra' sweet orange in different sucrose and MS concentrations, also found that the best development of embryos was achieved using diluted MS ( $75 \%$ of the original concentration), with

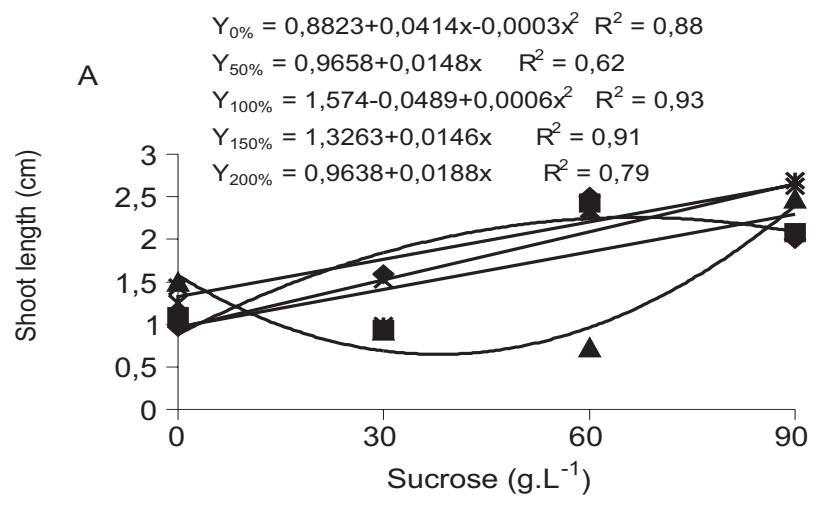

$\mathrm{Y}_{0 \%}=0,0048+0,0015 \mathrm{x}-0,00001 \mathrm{x} \quad \mathrm{R}^{2}=0,97$

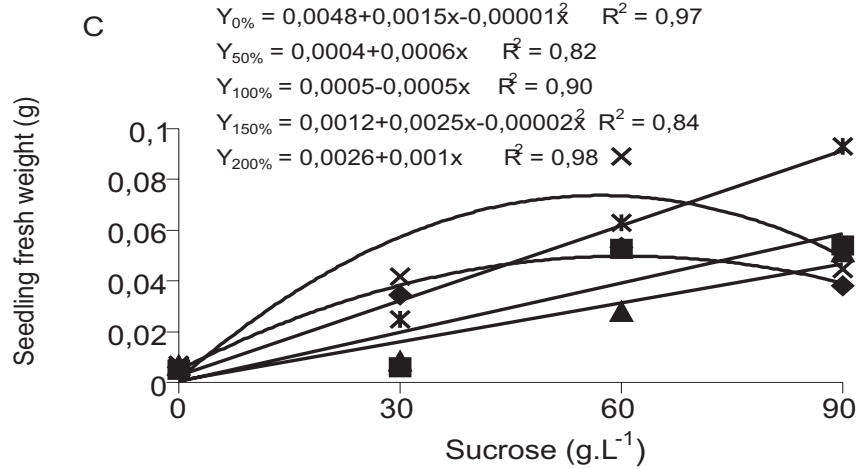

added sucrose $\left(60\right.$ g.L $\left.\mathrm{L}^{-1}\right)$.

Studying embryos of 'Poncã' mandarin, Pasqual et al. (2002) verified that the best growth and development were reached using MS at its original concentration, supplemented with 15 to $30 \mathrm{~g} . \mathrm{L}^{-1}$ of sucrose. Similarly, Tomaz et al. (2001) obtained more seedlings of the variety 'Seleta Vermelha' when embryos were grown in culture medium with 15 g. $\mathrm{L}^{-1}$ of sucrose, while for 'Cravo' mandarin, a high number of seedlings was obtained with 25 g.L.-1 of sucrose. Ricci et al. (2002) also induced the formation of more seedlings of 'Valência' sweet orange and 'Poncã' mandarin growing embryos in MT medium with 20 and 25 g. $\mathrm{L}^{-1}$ of sucrose, respectivelly.

At $0 \%$ of medium embryos have not developed adequately and the addition of higher concentrations of sucrose was not enough to substitute the lack of MT. On the other hand, at $200 \%$ of MT seedlings have shown intermediate performance in the absence of sucrose, and the development worsened with the addition of increasing concentrations of sucrose (Figure 1).

In the presence of low MT concentration (50\%), higher root growth was observed, probably as a way of better exploring the medium and increase nutrient uptake. Otherwise, when medium concentrations were higher (100\% and $150 \%)$, seedling roots did not develop so well (Figure 1B).

\section{Experiment 2 - vitamins $x$ sucrose}

This experiment confirmed how essential sucrose is to growth and development of the immature embryos of the hybrids, being the source of energy most commonly used in embryo culture of many species (Pasqual et al., 2001), including citrus immature embryos (Navarro et al., 1985; Pasqual \& Pinto, 1988; Caldas et al., 1998; Carimi et al., 1998; Ribeiro et al., 1998; Tomaz et al., 2001; Ricci et al., 2002; Pasqual et al., 2002). Vitamins have not shown to be totally necessary to the embryos studied here, becuase their absence resulted in good response to all variables determined in the experiment (Figuras 2A, 2B, 2C e 2D), in
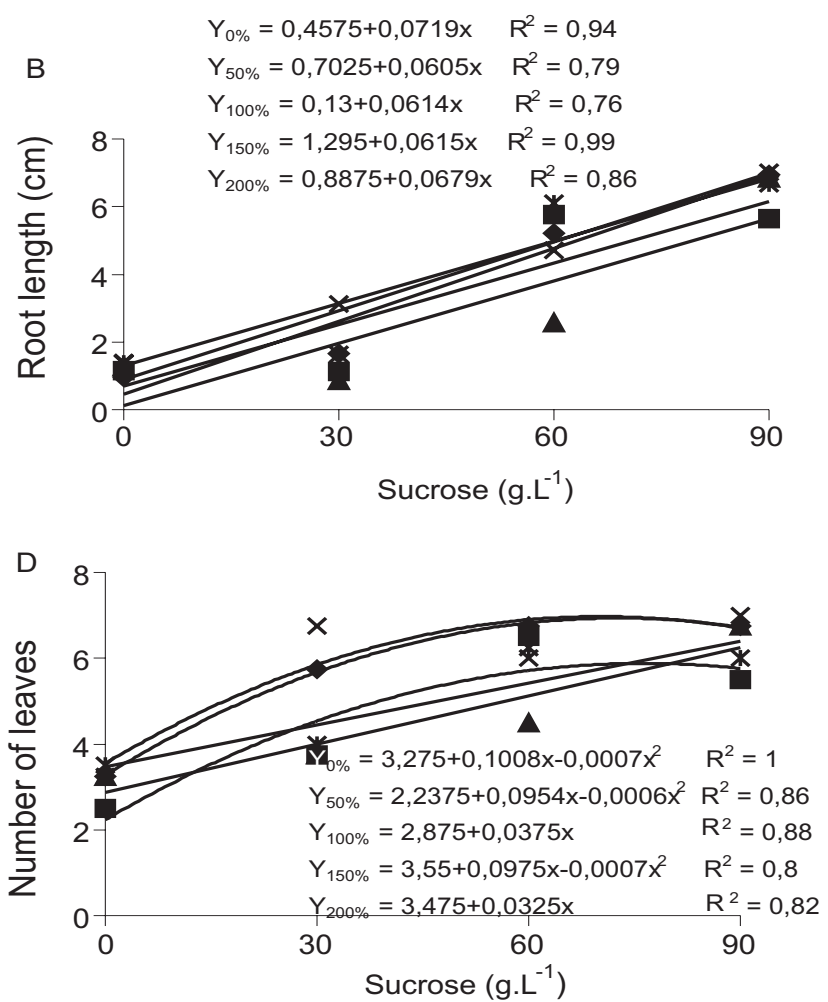

x $150 * 200$

FIGURA 2 - Shoot length (A), root length (B), fresh weight (C) and number of leaves (D) of the seedlings from immature embryos of the controlled crossing between 'Pêra Rio' sweet orange and 'Poncã' mandarin as grown in different concentrations of vitamins of the medium MT and sucrose. UFLA, Lavras, MG, 2002. 
accordance with Pasqual et al. (2001) who mentioned that embryos are capable of synthesizing these vitamins. However, this research has shown better responses to sucrose levels when associated with higher levels of vitamins. (Figure 2C).

Even though vitamins are frequently used according to the formulation of Murashige \& Skoog (1962), Linsmaier \& Skoog (1965) showed that only thiamine was essential to the growth of tobacco callus and therefore suggested an increase in the concentration of this vitamin to $0.4 \mathrm{mg} . \mathrm{L}^{-1}$ and the elimination of pyridoxine and nicotinic acid, because the latter are a little inhibitory to growth. To some species grown in vitro, it is necessary to increase vitamins concentration, as observed by Chatuverdi \& Mitra (1974) studying Citrus somatic tissues, but this observation is not valid to the globular embryos of this research.

According to Caldas et al. (1998), vitamins have important roles in photosynthesis and biosynthesis of amino acids, amongst other compounds. This way, the benefic effect of the addition of a certain vitamin to the medium is highly dependant of the capacity of each tissue or organ to synthesize it. On the other hand, complex mixtures like yeast extract, malt extract and hydrolyzed casein, provide a group of amino acids (Steinhart et al., 1961) that stimulates in vitro growth of many species (Caldas et al., 1998; Yatazawa \& Furuhashi, 1968). It is probable then that the high concentration of these components already present in the medium used in this study supplied the absence of vitamins and induced little effect when vitamins were added (Figure 2).

Hu \& Ferreira (1998), mention that malt extract and hydrolyzed casein are commonly used in the culture medium to stimulate embryo growth and development. The importance of the malt extract in the culture of citrus embryos was verified by Carimi et al. (1998) since they observed good results from the substitution of sucrose by $5 \mathrm{~g} . \mathrm{L}^{-1}$ of malt extract. Ghazvini \& Shirani (2002) also observed that $300 \mathrm{mg} . \mathrm{L}^{-1}$ of malt extract increased the formation of citrus embryos and Rangan et al. (1969) succesfully grew embryos of Citrus aurantium in White medium supplemented with $400 \mathrm{mg} . \mathrm{L}^{-1}$ of hydrolyzed casein. Many other works also show the importance of malt extract and hydrolyzed casein in embryo culture (Zdrujkovskala-Richter, 1981; Gmitter et al., 1990; Jumin \& Nito, 1996; Glória et al., 2000). Associating the information found in the literature with the results of this research, it can be affirmed that malt extract and hydrolyzed casein could supply the absence of vitamins for the survival of the embryos studied. However, the data presented in Figure $2 \mathrm{C}$ suggest that the addition of vitamins can result in more vigorous seedlings and maybe with a higher potential of development.

\section{Experiment 3 - activated charcoal $x$ gibberellin}

The use of $0.01 \mathrm{mg} . \mathrm{L}^{-1}$ of $\mathrm{GA}_{3}$ in the absence of activated charcoal resulted in higher length of roots, fresh weight and number of leaves (Figuras 3B, 3C e 3D). The low need of gibberellic acid observed through variables can be explained by the fact that embryos can synthesize this hormone Jiménez et al. (2001). However, it was necessary to supplement gibberellic acid in the culture medium to promote better development of embryos (Figure 3) as also observed by (Norstog, 1979).

These results corroborate with Ribeiro et al. (2000) who observed that supplementing MS with $0.01 \mathrm{mg} \cdot \mathrm{L}^{-1}$ of GA favored the growth and development of embryos from the crossing between Citrus limonia and Poncirus trifoliata. Das et al. (2000), studying zygotic and
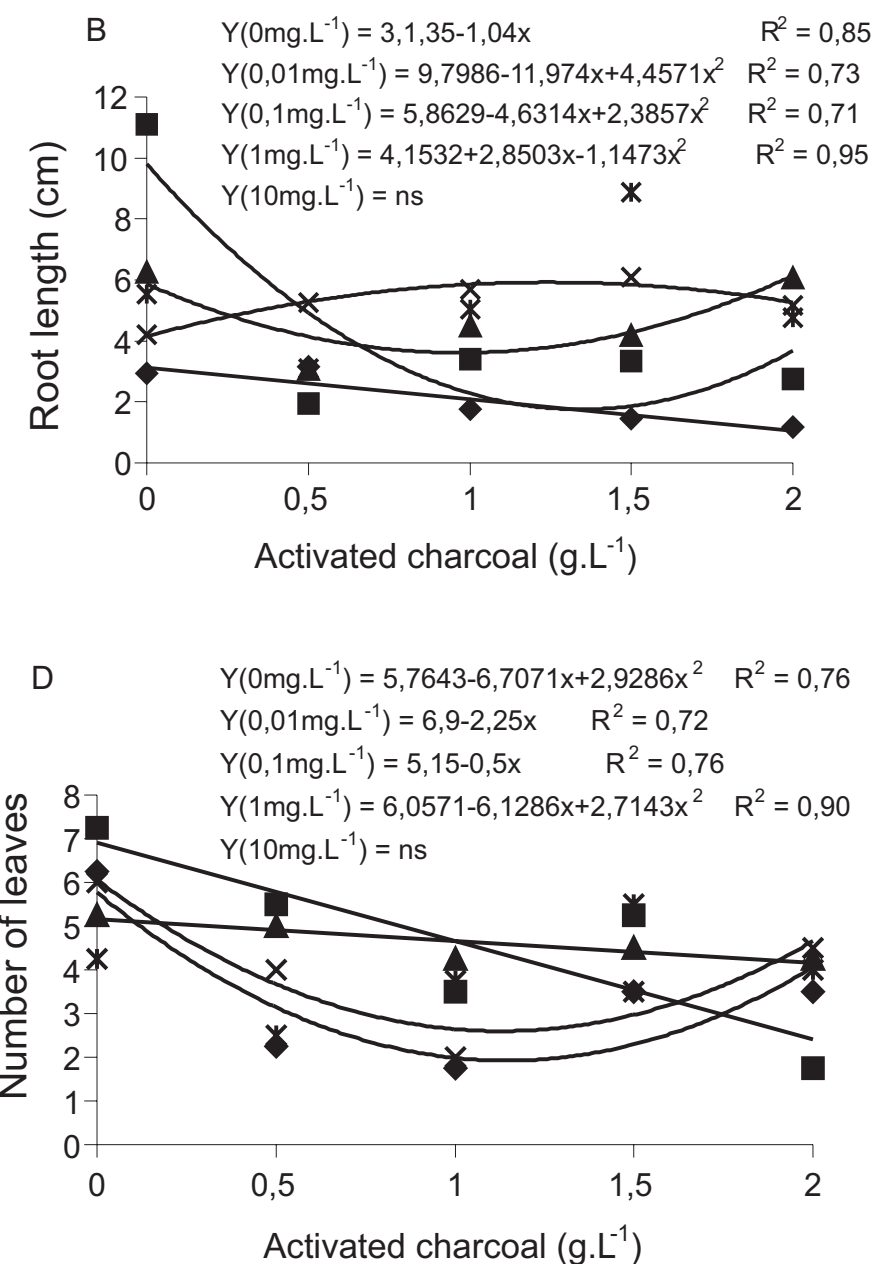

Activated charcoal $\left(\mathrm{g} \cdot \mathrm{L}^{-1}\right)$

$Y\left(0 \mathrm{mg} \cdot \mathrm{L}^{-1}\right)=0,0127+0,0222 x-0,0105 x^{2} \quad \mathrm{R} 2=0,69$

$\mathrm{Y}\left(0,01 \mathrm{mg} \cdot \mathrm{L}^{-1}\right)=0,0753-0,1034 \mathrm{x}+0,0408 \mathrm{x}^{2} \mathrm{R} 2=0,72$

$Y\left(0,1 \mathrm{mg} \cdot \mathrm{L}^{-1}\right)=0,0744-0,0771 \mathrm{x}+0,0365 \mathrm{x}^{2} \quad \mathrm{R} 2=0,80$

$\mathrm{Y}\left(1 \mathrm{mg} \cdot \mathrm{L}^{-1}\right)=0,0551-0,0351 \mathrm{x}+0,019 \mathrm{x}^{2} \quad \mathrm{R} 2=0,78$

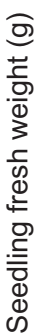

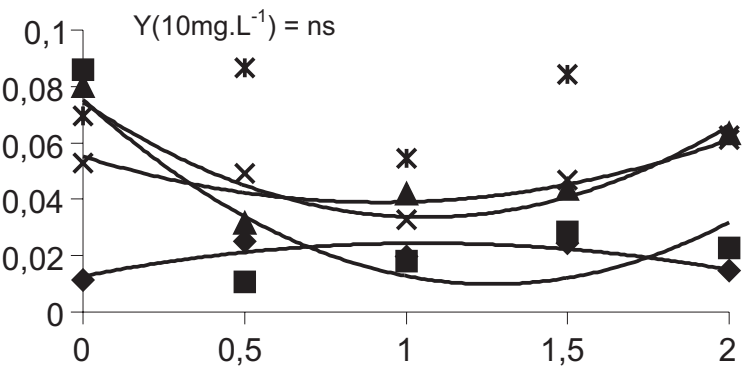

0

$\Delta 0,1$

$\mathrm{x} 1 * 10$

FIGURA 3 - Shoot length (A), root length (B), fresh weight (C) and number of leaves (D) of the seedlings from immature embryos of the controlled crossing between 'Pêra Rio' sweet orange and 'Poncã' mandarin as grown in different concentrations of activated charcoal and GA in the medium MT. UFLA, Lavras, MG, 2002. 
nucellar embryos of sweet orange grown in MS medium observed that $1 \mathrm{mg} . \mathrm{L}^{-1}$ of $\mathrm{GA}_{3}$ promoted better seedling formation. These authors suggested that depending on the species or variety, $\mathrm{GA}_{3}$ concentrations above $1 \mathrm{mg} . \mathrm{L}^{-1}$ are not good for the development of embryos, as also observed by Jarvis (1986). The results of this experiment disagree with those where 0.1 mg.L-1 (Pasqual et al., 1990; Jumin \& Nito, 1996), 1 mg.L-1 (Kunitake et al., 1991; Carimi et al., 1998) or 2 mg.L.' (ZdrujkovskajaRichter, 1981; Gmitter et al., 1990) of GA allowed better results in in vitro embryo culture. It is possible that this controversy is related to the presence of other medium components like the activated charcoal, because this component reduced the effect of the $\mathrm{GA}_{3}$ added to the medium (Figure 3). According to some authors, the activated charcoal is capable of sorbing toxic substances released by the explants or even by the medium, being useful in some cases (Grattapaglia \& Machado, 1998; Ricci et al., 2002). However, the results suggest that the activated charcoal can also adsorb $\mathrm{GA}_{3}$ from the medium, reducing the effect of higher concentrations.

Tomaz et al. (2001) observed that the activated charcoal had negative effect upon the germination of 'Seleta Vermelha' embryos, suggesting that this component can adsorb other compounds important to the germination, because the number of germinated embryos was $16 \%$ higher in the medium with $25 \mathrm{~g} . \mathrm{L}^{-1}$ of sucrose and no charcoal.

Although the presence of activated charcoal disfavored the root length, fresh weight and number of leaves, its supplementary effect to $\mathrm{GA}_{3}$ stimulated the stem elongation reflecting in higher shoot length (Figure 1A).

\section{CONCLUSIONS}

1) The best development of globular embryos from the hybridization between 'Pêra Rio' sweet orange and 'Poncã' mandarin was obtained with the use of $50 \%$ or $100 \%$ of the MT medium, supplemented with 60 to 90 g. $\mathrm{L}^{-1}$ of sucrose.

2) The vitamins of the MT medium did not show to be essential to in vitro culture of globular embryos from the hybridization between 'Pêra Rio' sweet orange and 'Poncã' tangerine.

3) The addition of $0.01 \mathrm{mg} \cdot \mathrm{L}^{-1}$ of GA, without activated charcoal provides better conditions to the development of globular embryos from the hybridization between 'Pêra Rio' sweet orange and 'Poncã' tangerine.

\section{REFERENCES}

AMMIRATO, P.V.; ESTEWARD, F.C. Some effects of environment on the development of embryos from cultured free cells. Botanical Gazette,v.132, p.149-158, 1971.

ANDREOLI, C. Cultura de embriões. In: SIMPÓSIO DE CULTURA DE TECIDOS VEGETAIS, 1., 1985, Brasília. Anais... Brasília: ABCTP/ EMBRAPA, 1986. p.25-28.

CALDAS, L.S.; HARIDASAN, P.; FERREIRA, M.E. Meios nutritivos. In:TORRES, A.C.; CALDAS, L.S. ; BUSO, J.A. (Ed.). Cultura de tecidos e transformações genéticas de plantas. Brasília, EMBRAPA, CBAB, 1998. p. 87-132.

CARIMI, F.; PASQUALE, F. de; PUGLIA, A.M. In vitro rescue of zygotic embryos of sour orange, Citrus aurantium L., and their detection based on RFLPanalysis. Plant Breeding, v.117, n.3, p.261-266, 1998.

CHATUVERDI, H.C.; MITRA, G.C. Clonal propagation of Citrus from somatic callus cultures. HortScience, v.9, p.118-120, 1974.

CROCOMO, O.J.; CABRAL, J.B. A biotecnologia no melhoramento de plantas tropicais. Brasília: Associação Brasileira de Educação Agrícola Superior, 1988. 39p. (Curso de Agricultura Tropical. Módulo I: O Ambiente e as Plantas Tropicais).

DAS, A.; PAUL, A.K.; CHAUDHURIS, S. Micropropagation of sweet orange Citrus sinensis Osbeck for the development of nucellat seedling. Indian Journal of Experimental Botany, v.38, n.3, p.269272,2000 .
FERREIRA, D.F. Análises estatísticas por meio do SISVAR para Windows versão 4.0. In: REUNIÃO ANUAL DA REGIÃO BRASILEIRA DA SOCIEDADE INTERNACIONAL DE BIOMETRIA, 45., 2000, São Carlos. Anais... São Carlos. 2000.

GEORGE, E.F. The components of culture media. In: GEORGE, E.F.; SHERRINGTON, P.D. Plant propagation by tissue culture: party 1 . The technology. Eversley, England: Exegetics, 1993. p.273-343.

GHAZVINI, R.F.; SHIRANI, S. Study of the effects of somatic embryogenesis of unfertilized ovules from Mexican lime (Citrus aurantifolia L.) on different media. Journal of Science and Technology of Agriculture and Natural Resources, v.6, n.2, p.4452,2002.

GLORIA, F.J.M. da.; MOURÃO FILHO, F. deA.A.M.; MENDES, B.M.J. Plant regeneration from protoplast of Brazilian citros cultivars. Pesquisa Agropecuária Brasileira, Brasília, v.35, n.4, p.727-732, 2000.

GMITTER, F.G.; LING, X.B.; DENG, X.X. Induction of triploid Citrus plants from endosperm calli in vitro. Theory Applied Genetic, v.80, p.785-790, 1990.

GRATTAPAGLIA, D.; MACHADO, M.A. Micropropagação. In: TORRES, A.C.; CALDAS, L.S. ; BUSO, J.A. (Ed.). Cultura de tecidos e transformações genéticas de plantas. Brasília: EMBRAPA/CBAB, 1998. p.183-260.

HU, C.Y.; FERREIRA, A.G Cultura de embriões. In: TORRES, A.C.; CALDAS, L.S.; BUSO, J.A. (Ed.). Cultura de tecidos e transformação genética de plantas. Brasília: EMBRAPA/CNPH/CBAB, 1998. v.2, p.371-393.

JARVIS, B.C. Endogenous control of adventitious rooting in non-woody cuttings. In: JACKSON, M.B. New root formation in plants and cuttings. Dordrecht: Martinus Nijhoff, 1986. p.191-222.

JIMENEZ, V.M.; GUEVARA, E.; BANGERTH, F. Endogenous hormone levels in habituated nucellar Citrus callus during the initial stages of regeneration. Plant Cell Reports, v.20, n.1, p.92-100, 2001.

JUMIN, H.B.; NITO, N. Plant regeneration via somatic embryogenesis from protoplast of six plant species related to Citrus. Plant Cell Reports, v.15, n.5, p.332-336, 1996.

KUNITAKE, H. KAGAMI, H.; MII, M. Somatic embryogenesis and plant regeneration from protoplasts of 'Satsuma' mandarin (Citrus unshiu Marc.). Scientia Horticulturae, v.47, p.27-33, 1991.

LINSMAIER, E.M.; SKOOG, F. Organic growth factor requirements of tobacco tissue cultures. Physiologia Plantarum, v.18, p.100-127, 1965.

MORAIS, L.S. Ajuste do meio de Murashige e Tucker (MT) para o cultivo in vitro de embriões imaturos de tangerina "Cleópatra" 1997. 86p. Dissertação (Mestrado em Fitotecnia)-Universidade Federal da Bahia, Cruz das Almas, BA.

MURASHIGE, T.; SKOOG F. A revised medium for rapid growth and bioassays with tobacco tissue cultures. Physiologia Plantarum, Copenhagen, v.15, n.6, p.473-479, 1962.

MURASHIGE, T.; TUCKER, D.P.H. Growth factor requirement of citrus tissue culture. In: INTERNACIONAL CITRUS SYMPOSIUM, 1. , Riverside, 1969. Proceedings. Riverside: University of California, 1969. v.3, p.1155-1169.

NAVARRO, L.; ORTIZ, J.M.; JUAREZ, J. Aberrant citrus plants obtained by somatic embryogenesis of nucelli cultures in vitro. Hortscience, v.20, p.214-215, 1985.

NORSTOG, K.J. Embryo culture as a tool in the study of comparative and development morphology. In: SHARP, W.R. et al. (Ed.). Plant cell and tissue culture. Columbus: Ohio State University, 1979. p.197-202.

PASQUAL, M.;ALVES, G.P.; DUTRA, L.F.; FINOTTI, D.R.; CHAGAS, E.A. Cultivo in vitro de embriões imaturos da tangerineira 'Poncã': concentrações do meio MS e da sacarose. Revista Ceres, Viçosa, v.49, n.282, p.181-189, 2002.

PASQUAL, M.; PINTO, J.E.B.P. Cultura de embriões. Notícias da Associação Brasileira de Cultura de Tecidos de Plantas, v.9, p.2- 
12, 1988.

PASQUAL, M.; RAMOS, J.D.; DUTRA, L.F. Aplicações no melhoramento genético de plantas. 2001. 79p. Curso de PósGraduação "Lato Sensu" (Especialização em Cultura de Tecidos Vegetais: tecnologia e aplicações)-Universidsade Federal de Lavras, Lavras.

PASQUAL, M.; RIBEIRO, V.G.; RAMOS, J.D. Influência do GA, e do carvão ativado sobre o enraizamento in vitro de embriões de laranja "Natal". Pesquisa Agropecuária Brasileira, Brasília, v.25, n.10, p.1477-1482, 1990.

RANGAN, T.S.; MURASHIGE, T.; BITTERS, W.P. In vitro studies of zygotic and nucellar embryogenesis in Citrus. In: INTERNATIONAL CITRUS SYMPOSIUM, 1., 1969, Riverside. Proceedings... Riverside: International Society of Citriculture, 1969. v.1, p.225-229.

RIBEIRO, V.G PASQUAL, M.; RAMOS, J.D.; OLIVEIRA JUNIOR, A.F. de O.; CARVALHO, G.R. Influência do $\mathrm{pH}$ e do ágar sobre o cultivo in vitro de embriões de laranjeira 'Pêra'. Pesquisa Agropecuária Brasileira, Brasília, v.32, p.1147-1152, 1997.

RIBEIRO, V.G D.; PASQUAL, M.; RAMOS, J.D.; VICHIATO, M.; SANÁBIO, D. Cultivo in vitro de embriões de laranja 'Pêra': concentrações do meio MS e sacarose. Ciência e Agrotecnologia, Lavras, v.22, p.429-434, 1998.

RIBEIRO, V.G.; PASQUAL, M.; RAMOS, J.D.; BEARZOTI, E.; NETO, S.D. Estádios de desenvolvimento embrionário e localização do embrião zigótico em sementes de citros. Pesquisa Agropecuária Brasileira, Brasília, v.34, p.1327-1333, 1999a.

RIBEIRO, V.G; PASQUAL, M.; RAMOS, J.D.; CARVALHO, G.R.; OLIVEIRAJUNIOR,A.F. DE O. Influência do ágar e do $\mathrm{pH}$ sobre o cultivo in vitro de embriões de laranja 'Natal'. Revista Ceres, Viçosa, v.46 p.587-595, 1999 b.

RIBEIRO, V.G.; SANÁBIO, D.; SOUZA, C.N. de; LOPES, P.S.N.
BOCARDO, M.R.; PASQUAL, M. Efeitos de ácido giberélico e carvão ativado no cultivo in vitro de Citrus limonia Osbeck $\mathrm{x}$ Poncirus trifoliata (L.) Raf. Pesquisa Agropecuária Brasileira, Brasília, v.35, p.27-30, 2000.

RICCI,A.P.; MOURAO FILHO, F. de A.A.; MENDES, B.M.J.; PIEDADE, S.M. de S. Somatic embryogenesis in Citrus sinensis, Citrus reticulata and C. nobilis x C. deliciosa. Scientia Agrícola, v.59, n.1, p.41-46, 2002.

SHARMA, D.R.; KAUR, R.; KUMAR, K. Embryo rescue in plants - a review. Euphytica, v.89, p.325-337, 1996.

SHARP,W.R.; DOUGALL, D.K.; PADDOCK, E.F. Haploid plantlets and callus from immature pollen grains of Nicotiana and Lycopersicon. Bulletin Torrey Botanical Club, v.98, p.219-222, 1971.

SOOST, R.K.; CAMERON, J.W. Citrus. In: JANICK, J.; MOORE, J.N. (Ed.). Advances in fruit breeding. West Lafayette, Indiana: Purdue University, 1975. p.507-540.

SOOST, R.K.; WILLIANS, T.E.; TORRES,A.W. Identification of nucellar and zygotic seedlings of Citrus with leaf isozymes. HortScience, Alexandria, v.15, n.6, p.728-729, 1980.

STEINHART, C.E.; STANDIFERJR., L.C.; SKOOG, F. Nutrient requirements for in vitro growth of spruce tissue. American Journal of Botany, v.48, p.465-472, 1961.

TOMAZ, M.L.; MENDES, B.M.J.; MOURAO FILHO, F. de A.A.; DEMETRIO, C.GB.; JANSAKUL, N.; RODRIGUEZ,A.P.M. In vitro Cellular and developmental biology, Plant, v.37, n.4, p.446-452, 2001.

WHITE, P.R. Ahandbook of plant tissue culture. Lancaster, Pensylvania: Costel e Co, 1943.273p.

YATAZAWA, M.; FURUHASHI, K. Nitrogen sources for the growth of rice callus tissue. Soil Science and Plant Nutrition, v.14, p.73-79, 1968.

ZDRUJKOVSKAJA-RICHTER,A.I. Embryo cultures and development of new forms of plants. Moscow: University Moscow, 1981. (Abstr.). 